\title{
8 \\ INEQUALITY AND INTERGENERATIONAL MOBILITY IN INDIA
}

\author{
Himanshu
}

\section{Introduction}

Given the large number of India's poor, the focus of policy and academic debates has largely been on poverty reduction. Discussions on inequality have been rather muted. But another reason has also been the lack of good quality data measuring inequality and, more so, on the impact of inequality on growth, mobility and human development. Nonetheless, recent years have seen a rise in interest in measuring inequality and how it affects social and economic outcomes (Sen \& Himanshu 2004; Subramanian \& Jayaraj 2006; Himanshu 2007, 2015; Sarkar \& Mehta 2010; Chancel \& Piketty 2017; Mazumdar et al. 2017). While there is no data after 2012, analysis of trends based on income, consumption and assets suggests that inequality is high in India when compared to other countries with a similar level of economic development. This has now been confirmed economically, considering aspects of income, consumption and assets, but also human development, such as education, health and nutrition. The human development indicators reveal that India suffers from the twin problem of high levels of deprivation and low achievement on most indicators, but also from inequalities of access and achievement. More worrying than this are the trends over time that suggest a secular rise 
in inequality in almost all dimensions, with only some moderation in the most recent period. These inequalities are now clearly established and no longer a matter of debate.

The analysis also suggests that the rise in inequality coincides with the beginning of the economic reform period that occurred from 1991. Unlike the 1980s, which saw growth accelerate in the economy along with declining inequality, in the period after 2004-05 inequalities grew more slowly, but continued to rise. Incidentally, the period after 2004-05 also saw the fastest decline in poverty in the last three decades. While a more full analysis of the reasons for changes in inequality is beyond the scope of this paper, preliminary analysis suggests that the role of a sectoral pattern of growth, the changing nature of employment and workforce structure and rising unemployment have contributed to a worsening of income distribution. Poor working conditions, low wages and lack of job creation have been a feature of the Indian economy for the last three decades, but these trends have intensified in the last decade. The fact that this period of 'jobless growth' coincided with the period of fastest economic growth raises further questions on the nature of growth but also on inequality of outcome and opportunity. Moreover, there are concerns that employment quality has deteriorated in existing jobs, with a majority having been generated either in the unorganised ${ }^{1}$ sector or as informal jobs in the organised sector. With the rise of the unorganised sector and informal work, harsh working conditions without adequate pay or social security are being normalised.

On the other hand, increasing instances of crony capitalism obtaining a rising share of profits and squeezes in wage share have unambiguously contributed to increasing inequality. The mechanism of capital benefiting from a disproportionately large share of growth at the cost of labour is similar to the mechanism Piketty (2014) refers to in the case of developed countries during the same period. While the Indian Government's pro-poor initiatives have contributed to a faster reduction in poverty, they have also contributed to a moderation of the inequality increase.

The rise in inequality needs to be analysed not just in terms of its impact on future economic growth and distribution but also in terms of social and political stability in a country, like India, where horizontal inequalities

1 Unorganised sector enterprises are tiny enterprises with less than 10 workers or enterprises that lack electricity and employ less than 20 workers. 
based on caste, class, religion, race, gender and location prevail. ${ }^{2}$ Much of the discussion on inequality in India has, however, centred on economic inequality, with little focus on aspects of horizontal inequalities. Horizontal inequalities are embedded in social and political structures and affect citizens' access to basic services. Inequality in India is as much about rising income inequality as it is about inequality in education, health, nutrition, sanitation and opportunities. Although difficult to quantify, available evidence suggests a similar rise in inequality in these areas. The burden of these disparities is not borne uniformly across groups or generations. Historically marginalised groups such as Dalits (scheduled castes $^{3}$ ), tribal groups (scheduled tribes ${ }^{4}$ ) and Muslims are disadvantaged in access to wealth and employment opportunities but also in access to basic services, which leads to lower levels of health, nutrition and education. Even within these disadvantaged groups, patriarchal norms and social structures have led to women being further excluded from access to basic services. Women also suffer from intra-household discrimination and discrimination in the labour market and opportunities to pursue a livelihood. The existence of wage gaps and the low female workforce participation rate is a known feature of the Indian economy. These aspects worsened during 2004-11, when the economy grew at its highest rate but a decline in female workforce participation was also recorded.

Changes in the labour market and persistent horizontal inequality also affect future mobility of individuals and households by denying them access to basic skills and opportunities. The purpose of this paper is to document and analyse the trends in inequality in India, particularly in the last three decades. The paper also seeks to understand the role of inequality in relation to mobility of households and individuals. I begin by examining the trend in inequality in India in recent decades using standard indicators of income, consumption and assets, where available. I also include dimensions of inequality from village surveys. The next

2 Stewart (2002) defines horizontal inequalities as inequalities arising out of an individual's social position based on caste, race and gender.

3 Scheduled castes are the lowest group in the caste hierarchy. Previously described as untouchables, they have been victims of discrimination over centuries. Apart from untouchability, they have systematically been denied access to equal education and employment opportunities. The introduction of the post-independence reservation system improved these circumstances as it demands access to public education and employment proportional to the scheduled caste population. 4 Scheduled tribes are groups notified by the constitution. Historically excluded from mainstream society, they have also been disadvantaged in terms of access to education and employment. Similar to the scheduled castes, they are also beneficiaries of reservation in public education and employment proportional to their population share. 
section examines some of the reasons for the changing nature of inequality in India. I go on to consider the impact of inequality on mobility, using available secondary evidence and analysis of mobility using Palanpur surveys, which are perhaps the only longitudinal surveys (covering seven decades) with detailed information on individuals and households in a north Indian village. The paper concludes by presenting some issues for further research.

\section{Inequality in India}

Inequality in India has generally been analysed using consumption expenditure data. As is well-known, these underestimate the extent of inequality in the economy. Because these have been available since independence, however, they continue to be the major data source for tracking inequality over time. The information on income inequality is supplemented here with income surveys undertaken by the Indian Human Development Survey (IHDS), which are collected by the National Council of Applied Economic Research (NCAER) and University of Maryland and were conducted in 2005 and 2012 to provide information on consumption as well as income. While the IHDS surveys are only available for two time periods, they offer hitherto unavailable insight into income inequality. These suggest a higher level of inequality than previously assumed but also show a trend in inequality that is similar to that revealed by the consumption surveys. The data on wealth inequality, although not strictly comparable to income or consumption surveys, also supplement the information on inequality at the national level. We use the nationally available National Sample Survey Office (NSSO) surveys on debt and assets to compute measures of asset inequality. The data on taxes and top incomes made available by the World Inequality Database are useful indicators of income inequality at the top level of income distribution and highlight the extreme nature of that inequality. Finally, village surveys are used to examine the nature of inequality at the micro level. Despite issues of comparability and lack of data over time, these also confirm the high level of inequality in India. Not surprisingly, all the data sources broadly confirm the fact that inequality in India has been high during the last two decades, and continues to rise further, at a time when the economy has also been growing at its highest rate. 


\section{Consumption inequality}

The most accepted measure of inequality in India is based on the consumption expenditure surveys of the NSSO. Available since the 1950s, these have been the primary source for tracking inequality in the country. The data is considered to be a reliable source to study changes in the level of and trends in poverty, inequality and wellbeing. Although these are available for smaller annual rounds, the quinquennial surveys, which are based on a large sample size, have been used to analyse the trend in consumption inequality.

Table 8.1 provides estimates of measures of inequality from the NSSO consumption surveys. Inequality as measured by the Gini of consumption expenditure has seen a rising trend since 1993-94. Other measures of inequality confirm this finding. For example, the ratio of average consumption expenditure of the urban top 10 per cent to the rural bottom 10 per cent was stable between 1983 and 1993-94 but has since then increased. ${ }^{5}$

Consumption inequality as measured by Gini coefficient is shown in Figure 8.1. The all-India consumption Gini coefficient has increased from 0.3 in 1983 to 0.36 in 2011-12. While the rural Gini has seen a modest increase from 0.27 in 1983 to 0.29 in $2011-12$, it is the urban Gini that is driving overall inequality. The urban Gini has seen a rapid rise from 0.31 in 1983 to 0.38 in 2011-12. However, the two periods of growth acceleration, first in the 1980s and then after 1991, show contrasting trends. The acceleration in growth rate in the 1980s was accompanied by stagnant inequality and a decline in rural inequality. This trend reversed after 1993-94, however, following the introduction of economic reforms in 1991. The rise in inequality was seen in rural and urban areas and, while this moderated after 2004-05, it continued to show a rising trend, except for a marginal decline in the case of urban areas between 2009-10 and 2011-12.

5 An analysis of decile-wise monthly per capita expenditure (MPCE) growth and share of each decile shows that only the top 10 per cent has increased its share in consumption expenditure in the last three rounds. The share of the bottom 90 per cent has gone down over the years. The top 1 per cent now has a share of around 9 per cent in the total consumption expenditure. 
Table 8.1. Estimates of consumption inequality from NSSO consumption surveys

\begin{tabular}{|l|r|r|r|r|r|r|}
\hline & $\mathbf{1 9 8 3}$ & $\mathbf{1 9 9 3 - 9 4}$ & $\mathbf{2 0 0 4 - 0 5}$ & $\mathbf{2 0 0 9 - 1 0}$ & $\mathbf{2 0 1 1 - 1 2}$ \\
\hline Share of various groups in total national consumption expenditure \\
\hline Bottom 20\% & 9.0 & 9.2 & 8.5 & 8.2 & 8.1 \\
\hline Bottom 40\% & 22.2 & 22.3 & 20.3 & 19.9 & 19.6 \\
\hline Top 20\% & 39.1 & 39.7 & 43.9 & 44.8 & 44.7 \\
\hline Top 10\% & 24.7 & 25.4 & 29.2 & 30.1 & 29.9 \\
\hline Ratio of average consumption of various groups \\
\hline Urban top 10\% / Rural bottom 10\% & 9.53 & 9.43 & 12.74 & 13.86 & 13.98 \\
\hline Urban top 10\% / Urban bottom 10\% & 6.96 & 7.14 & 9.14 & 10.11 & 10.06 \\
\hline Urban top 10\% / Rural bottom 40\% & 6.47 & 6.84 & 9.40 & 10.11 & 10.16 \\
\hline Gini of consumption expenditure & 27.1 & 25.8 & 28.1 & 28.4 & 28.7 \\
\hline Rural Gini & 31.4 & 31.9 & 36.4 & 38.1 & 37.7 \\
\hline Urban Gini & 29.8 & 30.0 & 34.7 & 35.8 & 35.9 \\
\hline All India Gini
\end{tabular}

Note. All estimates are based on mixed recall period (MRP) estimates of consumption expenditure.

Source. Author's computation from NSSO unit-level data

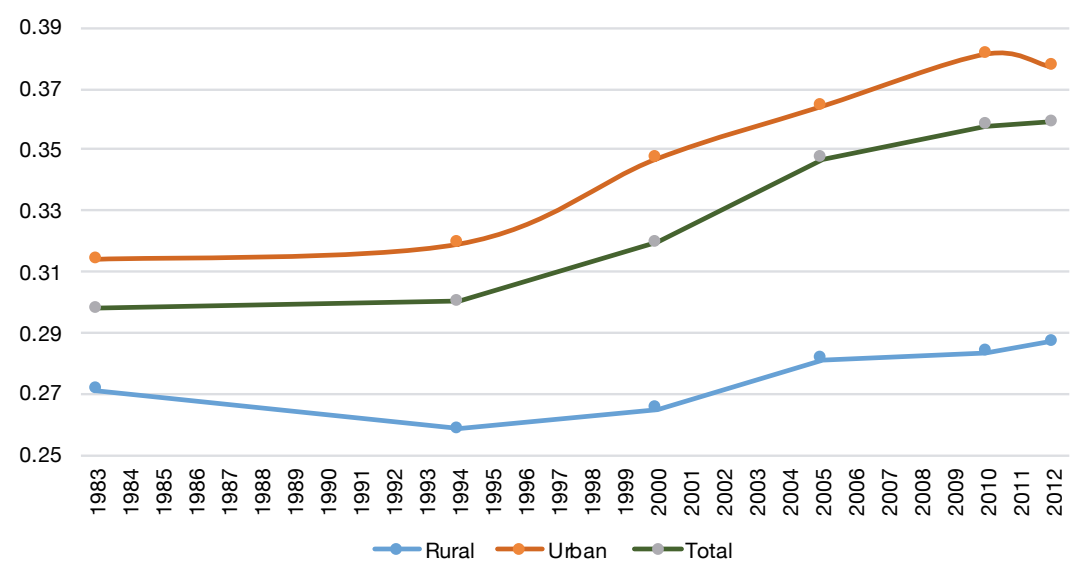

Figure 8.1. Gini coefficient of consumption expenditure (NSSO)

Note. All estimates are based on MRP estimates of consumption expenditure.

Source. Author's computation from NSSO unit-level data 
The analysis of the growth incidence curve using monthly per capita expenditure (MPCE) figures confirms the steep rise in inequality after 1993-94. Figure 8.2.1 and Figure 8.2.2 present the growth incidence curve using real MPCE by deciles adjusted for inflation using Consumer Price Index for Agricultural Labourers (CPI AL) for rural areas and Consumer Price Index for Industrial Workers (CPI IW) for urban. ${ }^{6}$ While urban MPCE growth outpaced rural MPCE growth, it was the upper deciles of MPCE within rural and urban areas that saw faster growth after 1991 as against the 1980s, when lower deciles saw faster growth.

The growth incidence curves confirm that it was the higher growth during the period of bottom deciles that contributed to a decline in overall inequality during the 1980s. This was true for both rural and urban areas, which saw higher growth of consumption expenditure among the lower deciles compared to the richer deciles in the 1980s. But we see a reversal of the trend after 1993-94, with lower consumption deciles growing slower than the richer deciles. This trend has continued after 2004-05 with a higher rate of growth of consumption across all deciles consistent with the high growth of economy achieved during this period.

Figure 8.3 presents the index of MPCE by rural and urban population groups. While there is not much divergence in the MPCE of various population groups between 1983 and 1994, the gap between various groups starts increasing after 1993-94. Between 1983 and 2012, while the urban bottom 40 per cent witnessed an increase of real MPCE by 51 per cent, the urban top 20 per cent witnessed an increase of 98 per cent. This confirms a faster rise in inequality in urban areas compared to rural areas.

6 The overall real MPCE grew at the rate of 1.72 per cent per annum in rural areas between 1983 to $1993-94$ and an almost similar rate of growth at 1.74 per cent per annum occurred in the urban areas. However, the growth rate of urban MPCE was higher in both 1993-94 to 2004-05 and 2004-05 to 2011-12. The growth rate of rural MPCE was 1.28 per cent between 1993-94 and 2004-05 and increased to 4.08 per cent per year between 2004-05 and 2011-12. The corresponding growth rates for urban areas were 1.51 per cent and 4.62 per cent per year. 


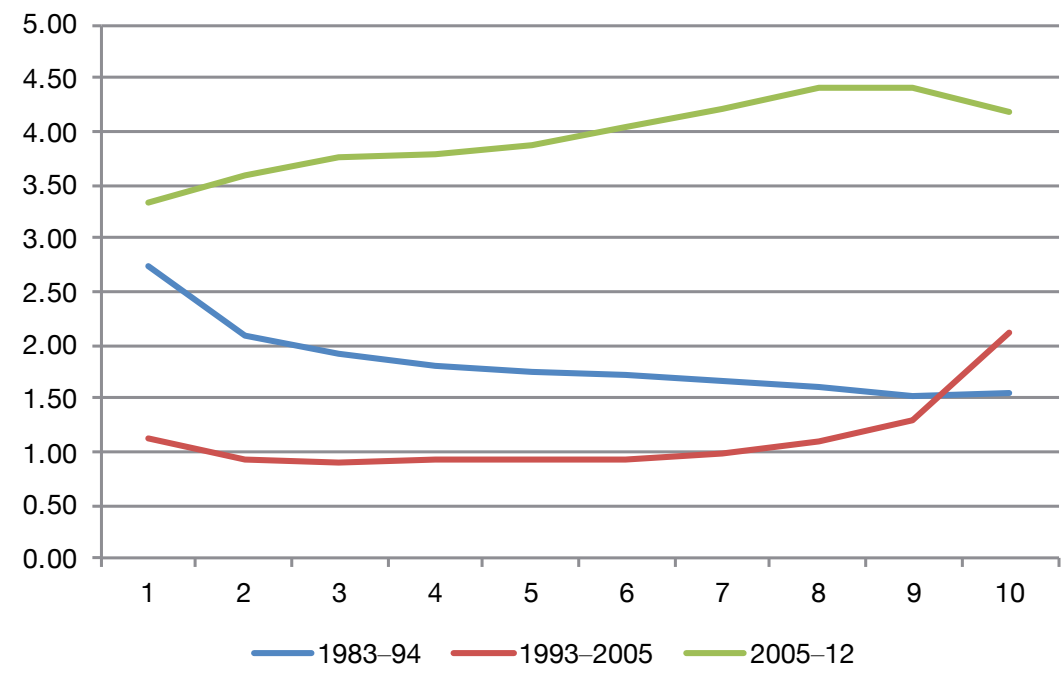

Figure 8.2.1. Growth rate of real MPCE by MPCE deciles (rural)

Note. All estimates are based on MRP estimates of consumption expenditure.

Source. Author's computation from NSSO unit-level data

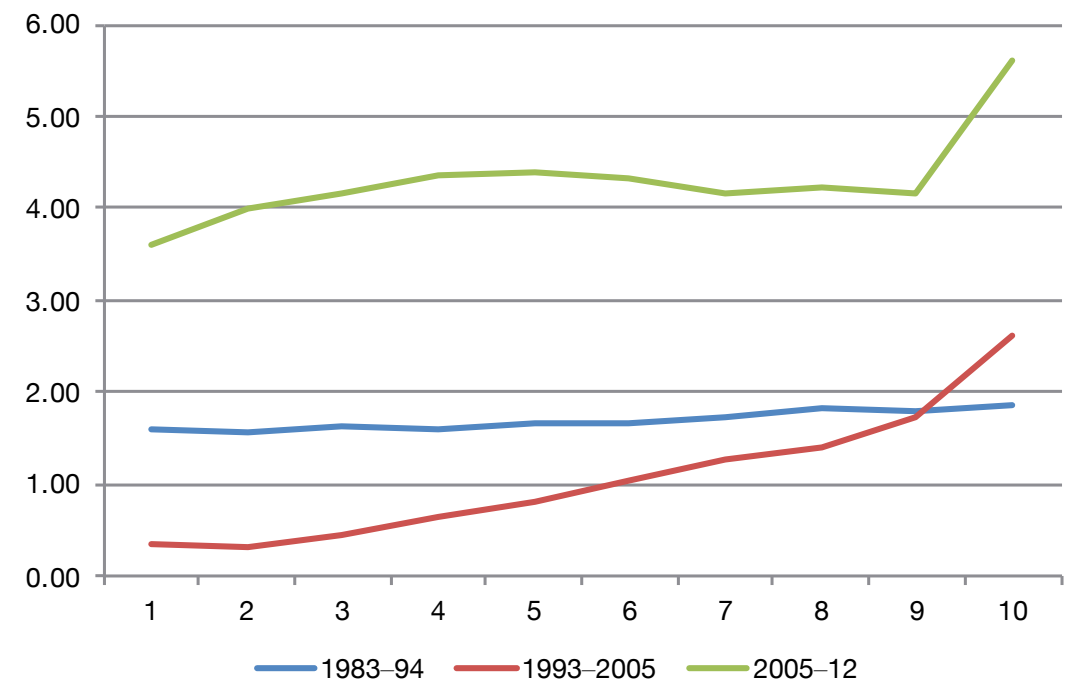

Figure 8.2.2. Growth rate of real MPCE by MPCE deciles (urban)

Note. All estimates are based on MRP estimates of consumption expenditure.

Source. Author's computation from NSSO unit-level data 


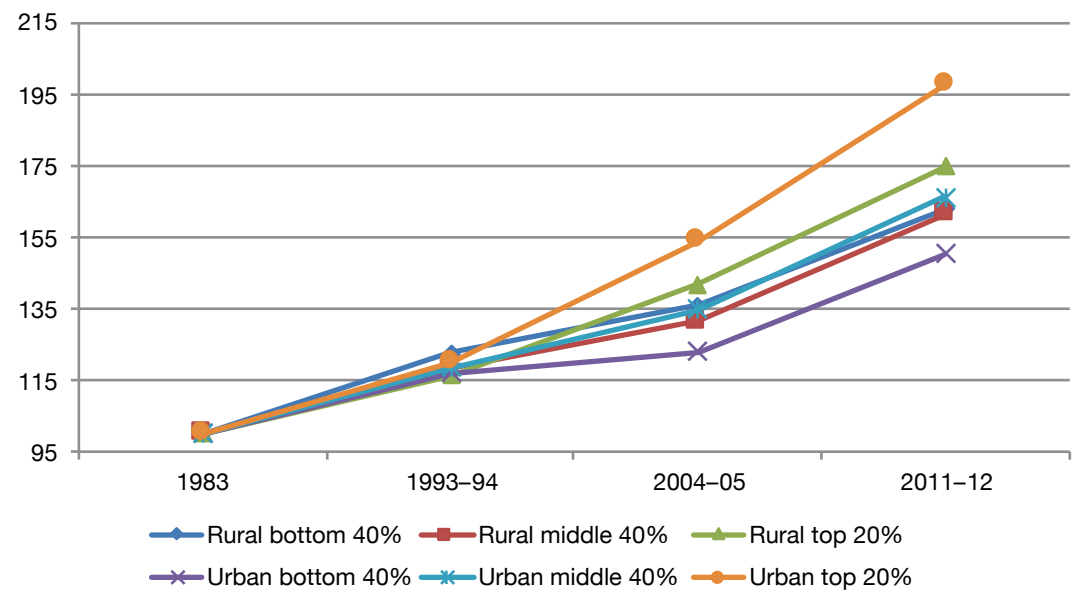

\section{Figure 8.3. Index of MPCE by groups $(1983=100)$}

Note. All estimates are based on MRP estimates of consumption expenditure.

Source. Author's computation from NSSO unit-level data

The pattern of growth across deciles is largely a reflection of the occupational profile of the households in each decile. Vulnerable categories of households, such as agricultural and other labouring households, have seen a lower increase in consumption expenditure than those in regular employment. Casual labour households in urban areas have also witnessed lower increases than the overall increase in consumption expenditure. One way to analyse these is to look at the ratio of consumption expenditure of these households compared to overall consumption expenditure. Table 8.2 presents these ratios for 1993-94, 2004-05, 2009-10 and 2011-12.

Table 8.2. Ratio of average MPCE of some occupation groups to average MPCE of all population

\begin{tabular}{|l|c|c|c|c|}
\hline \multirow{2}{*}{} & \multicolumn{2}{|c|}{ Rural } & \multicolumn{2}{c|}{ Urban } \\
\cline { 2 - 5 } & AL/All & OL/All & CAS/All & CAS/REG \\
\hline $1993-94$ & 0.78 & 0.95 & 0.61 & 0.54 \\
\hline $2004-05$ & 0.75 & 0.93 & 0.54 & 0.47 \\
\hline $2009-10$ & 0.77 & 0.91 & 0.54 & 0.46 \\
\hline $2011-12$ & 0.78 & 0.85 & 0.57 & 0.48 \\
\hline
\end{tabular}

Note. AL - agricultural labour, OL - other labour, CAS - casual labour, REG - regular workers.

Source. Author's computation from NSSO unit-level data 
Although improvement in the ratio of MPCE of agricultural labour households compared to all households is evident after 2004-05, it has worsened for other labour households. While average MPCE of other labour households was 95 per cent of all households' MPCE in 1993-94, this ratio was down to 85 per cent in 2011-12. Similarly, in urban areas, MPCE of casual labour households was 61 per cent of all households' MPCE but declined to only 54 per cent by 2009-10, although it improved marginally to 57 per cent in 2011-12. Also, MPCE of regular worker households has increased faster than MPCE of casual labour households in urban areas as reflected by the ratio of MPCE of casual to regular workers households.

\section{Income inequality}

Even though the consumption inequality estimates suggest a rising trend, there is a general belief that the level of inequality in India is low by international standards. ${ }^{7}$ Part of the reason for such an understanding is due to the fact that inequality in India is usually measured on consumption expenditure, which is not comparable to inequality in most countries where it is measured on income dimension. While there is no one-to-one correspondence between income and consumption inequality, evidence across countries suggests that consumption inequality is in general lower than income inequality. This is largely because consumption as measured in India by the NSSO tends to underestimate the consumption of the wealthy, but it is also because consumption is a smoothed measure unlike income. ${ }^{8}$ On comparable measures of consumption inequality, however, inequality in India is not low.

While there is comparable data over a long period of time on consumption distribution in India, there are a limited number of sources available as far as income inequality estimates are concerned. Those that are available are privately collected data sources and lack official estimates of income inequality. There is now, however, some information available from IHDS

7 According to the World Bank's world poverty and inequality databases, the consumption Gini for India was 33.4 for 2004-05 whereas comparative Gini coefficients for selected countries were: Brazil (56.9), China (42.5), Malaysia (37.9), Mexico (46.05), Russia (40.8), South Africa (67.4 in 2006), United Kingdom (37.6), United States (40.6) and Vietnam (36.8).

$8 \mathrm{Li}$, Squire and Zhou (1998) find that consumption inequalities are systematically lower compared to income inequality. Although they suggest that the gap between income and consumption inequality is around 6.6 Gini points, evidence from India on this count suggests that this gap may be anywhere close to 15 points. 
surveys that has been used to study inequality in household incomes. The Gini coefficient for household income in India, based on IHDS data, also shows an increase in inequality from 0.54 in $2004-05$ to 0.55 in 2011-12. Figure 8.4 presents the Gini coefficient by sector. However, unlike trends reported in the case of consumption and assets, IHDS reports higher inequality in rural areas compared to urban areas although both show a rise in inequality between the two surveys. The income Gini of 0.55 in 2011-12 puts India alongside the most unequal countries in the world. While the level of inequality in itself is worrying, the fact that it has increased since the previous period is more so.

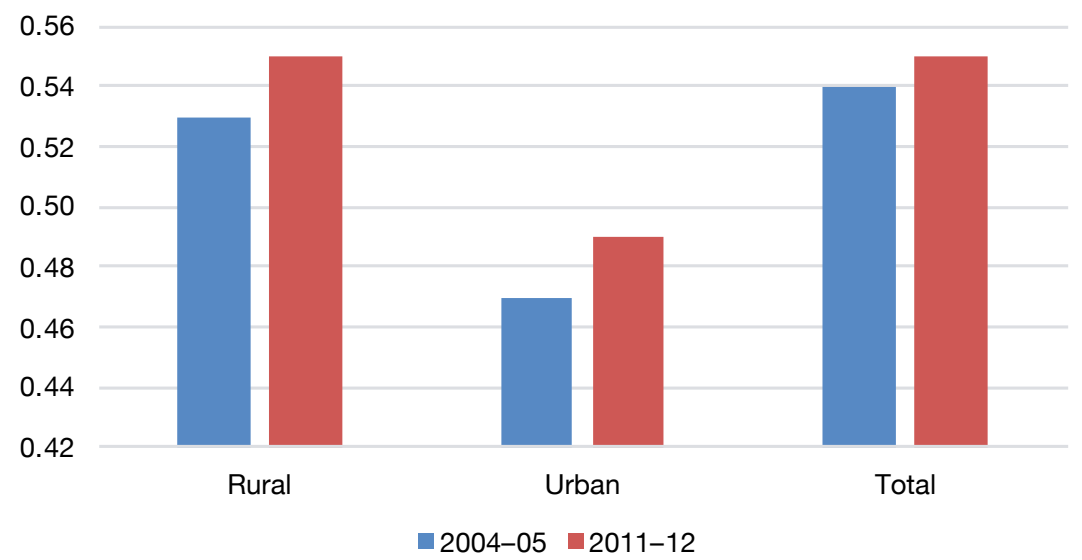

\section{Figure 8.4. Income inequality (IHDS)}

Source. Author's computation from IHDS unit data

Despite the fact that the IHDS is the only source of information on income inequality, its use is limited partly because of the longitudinal nature of data with a base of 2004-05. There are concerns that 2011-12 income inequality estimates from IHDS may not be the true income inequality measure for the country as a whole. ${ }^{9}$ There are also valid concerns on the quality of income data, particularly variation across states and across sectors over time.

9 Since IHDS-2 uses a panel of households with the sampling frame of IHDS-1, there are concerns that it may not be a representative sample for the country in 2011-12. Such concerns are usual with panel data. 


\section{Asset inequality}

Another dimension of inequality that has increased in recent decades is inequality in assets. These decadal data are available from the All-India Debt and Investment Survey (AIDIS) of the NSSO and are based on a large sample survey of household assets such as land, buildings, agricultural machinery, vehicles; and financial assets such as shares, debentures, and amounts outstanding. AIDIS also collects information on household debt, credit agencies and terms of debt. The survey provides information on physical quantities of assets and their present value in monetary terms. While the AIDIS gives a reasonable estimate of household wealth, it does not have information on corporate wealth. Equally, selfreported surveys are known to contain underestimates in valuations of household wealth in the form of land, buildings and jewellery. Therefore, the extent of inequality based on AIDIS data is, at best, at the lower scale of wealth inequality.

The AIDIS surveys were conducted in the 48th round (1991), 59th round (2002) and 70th round (2012) of the NSSO surveys. While the basic AIDIS questionnaire has remained the same, some changes have been made over the years. The 1991 surveys did not carry a question on household religion nor did they have the other backward class (OBC) category for social group. In the 70th round, the AIDIS survey did not collect information on household durables. To compare total wealth, the value of durables for 1991 and 2002 has been excluded. Another problem is the lack of suitable deflators for inter-temporal comparison. Despite these obvious limitations, the AIDIS data provides evidence of extremely high levels of wealth inequality and a deterioration of wealth distribution over the years.

The fact that wealth inequality estimates tend to be higher than consumption and income inequality is well known. This has also been confirmed in the case of India by earlier studies on wealth inequality (Vaidyanathan 1993; Subramanian \& Jayaraj 2006; and Jayadev et al. 2007). Subramanian and Jayaraj (2006) and Jayadev et al. (2007) analysed wealth inequality disaggregated by caste, occupation and states and highlighted the large discrepancy in wealth-holding across caste groups, occupational groups and across states. The level of wealth per capita was found to be similar to the hierarchy of the caste structure and occupational groups. Recent evidence based on the 2012 round of AIDIS by Anand and Thampi (2016) and Sarma et al. (2017) confirms the trend observed 
in the case of consumption and income inequality. Inequality based on assets has not only increased since 1991 but it has also been accompanied by increasing divergence in assets held by disadvantaged groups such as Dalits, tribal groups and Muslims. Analysis by Credit Suisse as part of its Global Wealth Report (GWR) (2017), which provides annual estimates of wealth inequality for a number of countries, also confirms the finding of a rapid rise in wealth inequality in the last two decades. ${ }^{10}$

Table 8.3 presents the share of wealth held by each decile. The bottom 50 per cent of the population held 9 per cent of total assets in the country in 1991, but that share has declined by one third to only 5.3 per cent by 2012 . As against this, the share of wealth held by the top 1 per cent has increased from 17 per cent in 1991 to 28 per cent by 2012. The top 10 per cent held more than 50 per cent of the wealth in all the survey years reported here, with the share rising from 51 per cent in 1991 to 63 per cent in 2012. Since estimates from the AIDIS exclude information on bullion and durables, the share of wealth held by the top 1 per cent and top 10 per cent is likely to be higher. Also, without data on corporate wealth, in all likelihood the share of the top 1 per cent is underestimated

Table 8.3. Decile-wise wealth share

\begin{tabular}{|l|r|r|r|}
\hline \multirow{2}{*}{ Wealth decile } & \multicolumn{3}{|c|}{ Percentage share of total wealth } \\
\cline { 2 - 4 } & \multicolumn{1}{|c|}{$\mathbf{1 9 9 1}$} & \multicolumn{1}{c|}{$\mathbf{2 0 0 2}$} & \multicolumn{1}{c|}{$\mathbf{2 0 1 2}$} \\
\hline 1 & 0.16 & 0.06 & 0.03 \\
\hline 2 & 0.85 & 0.60 & 0.41 \\
\hline 3 & 1.66 & 1.32 & 0.92 \\
\hline 4 & 2.59 & 2.15 & 1.56 \\
\hline 5 & 3.75 & 3.22 & 2.41 \\
\hline 6 & 5.24 & 4.67 & 3.58 \\
\hline 7 & 7.25 & 6.75 & 5.31 \\
\hline 8 & 10.41 & 10.21 & 8.29 \\
\hline 9 & 16.48 & 17.15 & 14.97 \\
\hline 10 & 51.61 & 53.87 & 62.52 \\
\hline Top 1\% & 16.94 & 17.06 & 27.60 \\
\hline
\end{tabular}

Source. Author's computation from AIDIS unit data

10 The annual Global Wealth Report bases its wealth data for India on the AIDIS survey but is further refined using regression techniques to fill the gap for intervening years. It also uses external data to rescale the wealth estimates. 


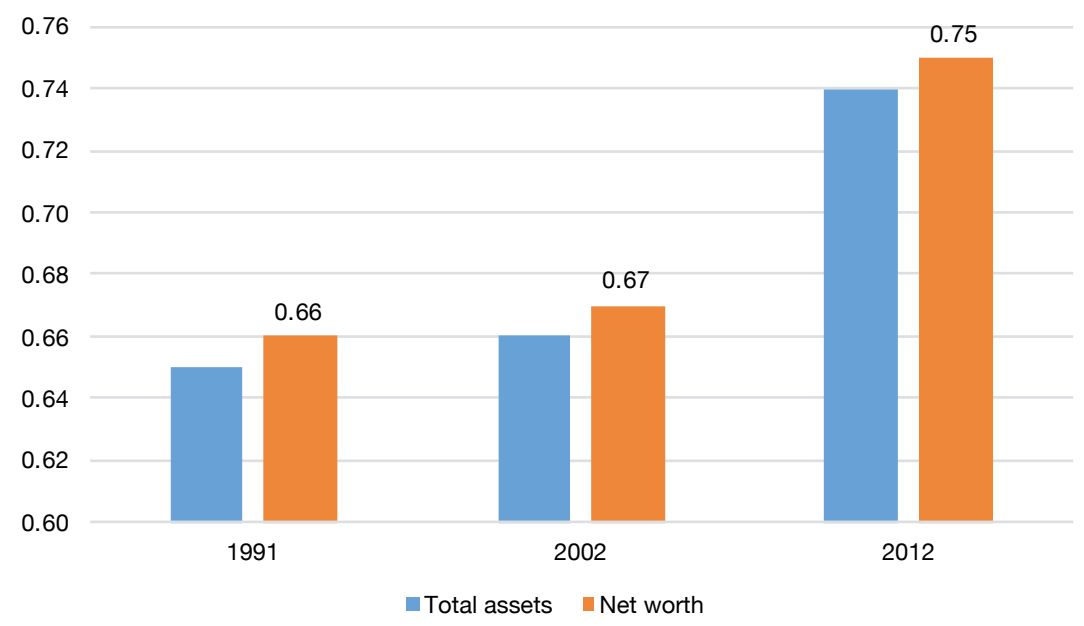

Figure 8.5. Gini coefficient of wealth (AIDIS)

Source. Author's computation from AIDIS unit data

The Gini wealth coefficients are presented in Figure 8.5. These are not only higher than the corresponding estimates of inequality based on income or consumption but also show an increase in the last two decades. While the increase was marginal in the 1990s, it has increased sharply in the last decade. Figure 8.5 also shows that, accounting for debt, net worth inequality is higher than asset inequality. Wealth inequality is in fact similar to estimates of inequality of land holding. Rawal (2008) reports the Gini of land ownership at 0.76 in 2003.

The 2017 GWR measures the Gini coefficient of wealth inequality in India at 0.83 . The GWR's corresponding estimate of Gini for wealth in 2011 reports it at 0.804 , which suggests an increase by 0.3 percentage points in the next six years. According to the GWR, the bottom 50 per cent of the Indian population held 8.1 per cent of total wealth in 2002, and this declined to 4.2 per cent by 2012. In contrast, the top 1 per cent of the population held 15.7 per cent of total wealth in 2002, and this increased to 25.7 per cent of total wealth by 2012 . Among the countries for which GWR gives figures, only the top 1 per cent in Indonesia and the United States have a higher wealth share than India. 


\section{Micro-level income inequality}

While aggregate inequality estimates are useful in tracking trends in income distribution, they mask regional-level variation. This is particularly so for village-level inequality, which is an important source of data, particularly for the rural economy. Wherever available, this data suffers from problems of comparability across villages and over time. While few surveys have time series longitudinal data spanning decades, the estimates available from village surveys for recent years confirm that the level of inequality at village level is also high. Most village surveys report estimates of inequality based on detailed calculation of income and, despite the methodological differences, suggest a high level of inequality consistent with other sources of information. Estimates of inequality in more recent village studies by the Foundation for Agrarian Studies (FAS) between 2005-08 show Gini coefficients ranging between 0.5 to 0.7 (Rawal \& Swaminathan 2011). FAS arrived at these estimates from data collected as part of the Project on Agrarian Relations in India (PARI) and report Gini for eight villages, three from Andhra Pradesh, two each from Uttar Pradesh and Maharashtra and one from Rajasthan. This range provides a general snapshot of villages based in different agro-climatic zones of the country and the results show an extreme concentration of wealth in the top decile. The share of the top income decile for per capita income from pooled data of all villages is reported as 48.06 per cent.

Swaminathan and Rawal (2011) also report a tendency for inequality to be higher among villages with higher per capita income (with the exception of two villages from Maharashtra). They also report the presence of negative income, primarily owing to losses in crop production. In an analysis of income by caste, the authors point to the absence of Dalit households from the top income quintile in all villages but one, and an over-representation in bottom quintiles. Despite the large variation in income inequality reported by most of the village surveys, there is some consensus that inequality has risen, rather than diminished, over time. ${ }^{11}$

\footnotetext{
11 Despite the wealth of information available across states and over time, these village surveys are not utilised as measures of inequality because of the inherent difficulty in comparability across village surveys. The variation is partly due to the difference in time period covered and the local context, but also the methodology used, with each survey having its own methodology of estimation of incomes. This is further compounded by the fact that most of the village surveys are based largely on agricultural incomes. On the other hand, very few have non-agricultural incomes included to the extent that secondary sources suggest may be relevant. For recent changes in income distribution through village surveys, see, Himanshu, Joshi \& Lanjouw (2016).
} 


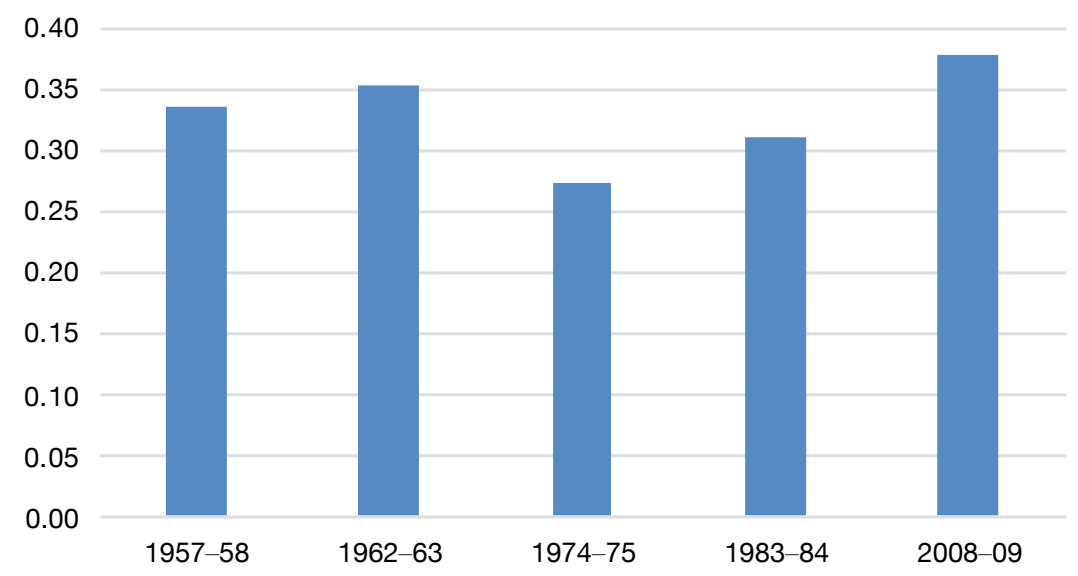

Figure 8.6. Inequality in Palanpur

Source. Himanshu, Joshi \& Lanjouw (2016)

While estimates of inequality reported by village surveys are similar to those reported by large-scale surveys, they are slightly higher than estimates reported by national surveys. Similar to national surveys, however, most longitudinal village surveys that have tracked inequality in villages over time report an increase in inequality in recent decades. Swaminathan (1988) reports a rise in inequality in Gokilapuram (Tamil Nadu) from 0.77 in 1977 to 0.81 in 1985 . Among the major longitudinal village surveys, Palanpur, a village in the north Indian state of Uttar Pradesh has been surveyed once in each decade, beginning in 1957-58. Figure 8.6 shows the reported Gini coefficient for incomes over the survey years for Palanpur. While inequality declined until 1974-75, which is similar to the national trend, the village has seen a steady rise in inequality since then, reaching the highest level in 2008-09. Between 1983-94 and 2008-09, inequality has increased despite a fall in poverty.

The broad picture emerging from secondary and primary surveys confirms not only that income inequality is high in India, but also that inequality during the last three decades has risen. While the evidence presented here suggests a trend of rising inequality in income and assets, inequality in terms of human development outcomes also suggests a widening of these disparities. 
Inequality in income/consumption and assets are as much a measure of inequality of opportunity as they are outcomes of economic processes. These are further compounded, however, by other inequalities that have a role in shaping inequality of opportunity. Individual/household mobility is also stimulated by access to education and healthcare. These in turn are also determined by an individual's/household's position in the social hierarchy. When access to opportunities is shaped by an individual's place of birth, caste, community, religion and gender, the social structure is more critical than access to assets and income because social inequality leads to marginalisation, exclusion and disadvantage. This inequality can be mediated by political and economic institutions, but also by the government, which has a democratic mandate to provide equal opportunities to all.

\section{What explains rising inequality in recent decades?}

The rise in inequality over recent decades has been among the fastest in the seven decades since independence, however, it has not attracted policy attention. This is partly because of the belief that increasing inequality is a necessary by-product of growth. ${ }^{12}$ But, in India's case, the two phases of growth acceleration, first in the 1980s and then again in the decade after 2004-05, do not justify that assumption. Most indicators suggest that the growth acceleration in the 1980s was accompanied by declining or stable inequality. The trends after the 1990s, however, suggest that the period after the economic reforms of 1991 has unambiguously led to increased inequality in multiple dimensions. Accelerated growth after 2004-05 has been accompanied by a moderate rise in inequality and more rapid reduction in poverty than earlier periods. Based on the trends reported above, there is evidence of three phases of inequality. The $1980 \mathrm{~s}$ was a period of reduced inequality followed by a sharp rise in the $1990 \mathrm{~s}$ following the economic reforms. This increase was moderated in the third phase after 2004-05.

12 This has some justification in the Kuznets curve argument that posits rising inequality as a result of rapid growth driven by growth in the industrial sector. Inequality reduces when growth broadens to encompass rural areas. 


\section{Sectoral pattern of growth}

Income distribution outcomes are strongly linked to outcomes in the labour market and the sectoral pattern of growth. The 1980s were a period of accelerated growth led by growth in non-farm and agricultural sectors. This growth rate from 1970 to 1980 of 1.5 per cent compares unfavourably with the 3.4 per cent growth recorded in the 1980s. Figure 8.7 presents the agricultural and non-agricultural growth rate since the 1980s. The post1991 acceleration was led by growth in the non-agricultural sector, with secular rise in non-farm growth rates. Agricultural growth rates, however, which were rising in the 1980s, declined at the beginning of the 1990s and only showed a trend to increase after 2004-05. Both periods of agricultural growth were accompanied by a decline in inequality as against the 1990s, which witnessed rising inequality. Agricultural growth leads to better returns to farmers, who are among the poorest in society, but it also contributes to rising wages for the casual workers.

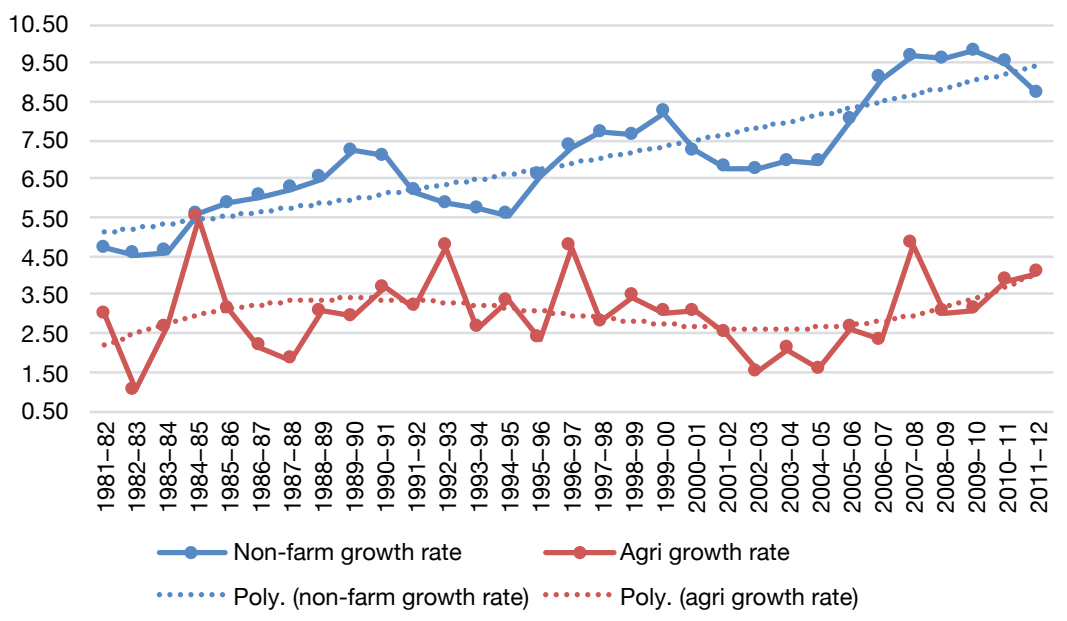

Figure 8.7. Growth rate in the agricultural and non-agricultural sectors (constant 2004-05 prices)

Source. National Accounts of India

While sectoral distribution of growth matters, inequality is also determined by the distribution of the benefits of growth among the various factors of production. As mentioned earlier, agricultural growth contributed to rising rural incomes and wage rises. But it also contributed to an increase in the pace of non-farm diversification. The 1980s witnessed the first wave of non-farm diversification in rural areas, with employment in the non-farm 
sector rising faster than the agricultural sector. Non-farm diversification was also a result of increased public spending, which contributed to the bottom deciles benefiting from access to non-farm jobs.

The trend of declining inequality was reversed, however, after the economic reform of 1991. The decline in subsidies and opening up of the economy affected job creation but also affected growth in the agricultural sector. The crisis in agriculture during 1997-2003, when growth decelerated to less than the rate of population growth affected a majority of the rural population. The agricultural sector also suffered from an increase in suicides by farmers as a result of economic changes. The period between 1991 and 2004-05 was clearly a period of rising inequality, including interpersonal and regional inequality.

\section{Inequality and labour market outcomes}

Policy and academic discourse has been concerned for some time at India's lack of job creation, even when the economy has been growing relatively rapidly (Figure 8.8). This has been a feature of economic growth since the 1990s, but has been accentuated since 2004-05, with job growth virtually collapsing. While almost 10 million working-age people enter the labour force annually, job creation stagnates at 2 million workers. Between 1993-94 and 2004-05, the annual addition to the workforce was 7.6 million per year. This fell to 2 million between 2004-05 and 2011-12. While recent estimates are not available from NSSO Employment-Unemployment Surveys (EUS), Abraham (2017) reports a net decline in the number of workers after 2014 based on Labour Bureau employment surveys. The extent of job losses after 2014-15 has also been confirmed by the Centre for Monitoring Indian Economy (CMIE).

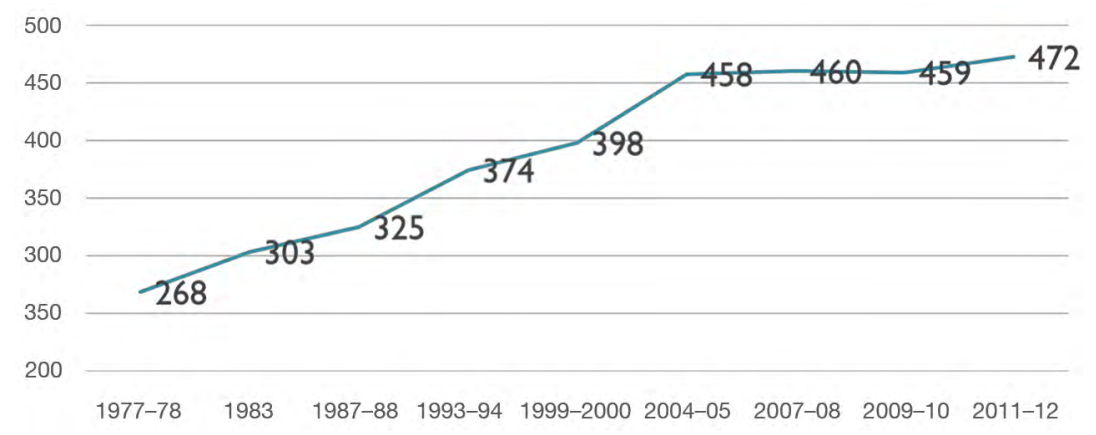

Figure 8.8. Number of workers

Source. Employment-unemployment surveys of NSSO 
Inequality in the labour market also arises from the skewed distribution of workers across sectors. Around half of India's workforce is employed in the agricultural sector, despite the sector's falling share in gross domestic product (GDP). The growth of the agricultural sector has remained less than 2 per cent on average since 1991, with employment in agriculture increasing during the same period. A large share of the workers is also employed in the unorganised sector, even though its share of GDP has been falling. On the other hand, the sectors that have grown the fastest, such as finance, insurance, real estate and IT-related services and telecommunications, employ less than 2 per cent of the workforce. This has led to increasing divergence between per-worker productivity in agriculture and construction, which are sectors with the lowest productivity, and workers in the fast-growing sectors. The ratio of labour productivity in the non-agricultural to agricultural sectors has increased from 4.46 in 1993-94 to 5.52 in 2011-12 (Dev 2017).

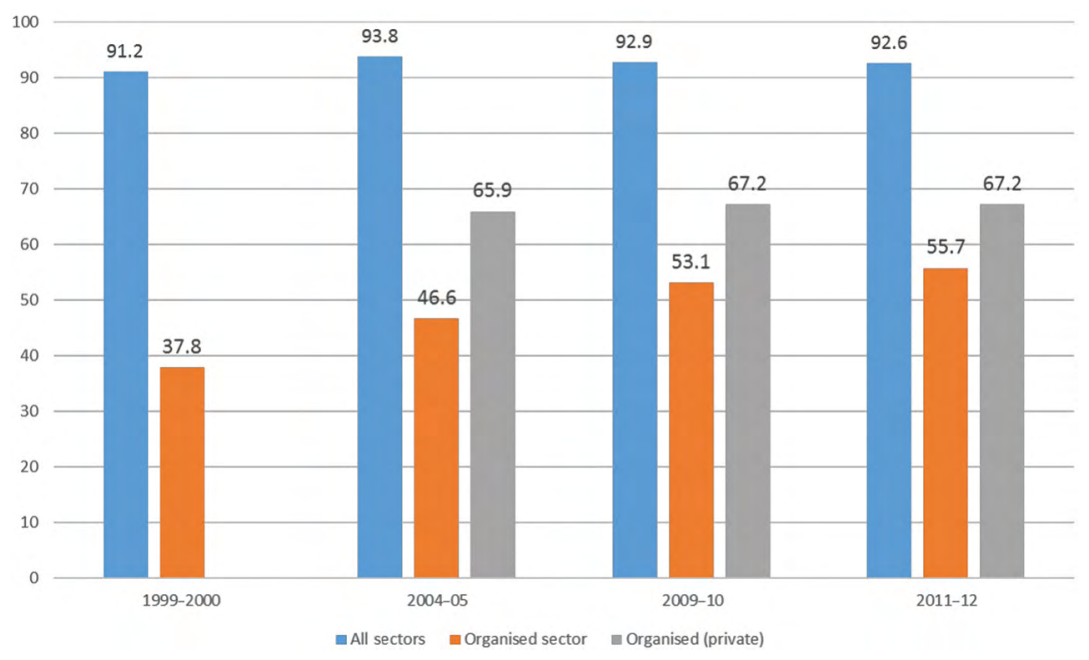

Figure 8.9. Percentage of informal workers by type of employment Source. NSSO

Another aspect of labour market inequality exists among those who are employed. While a large majority of workers are employed in the informal sector, with no social security, the organised sector has also seen a decline in employment quality over the years. Figure 8.9 gives the distribution of workers by type of employment. At the national level, 93 per cent of all workers are employed as informal workers. These are distributed throughout the unorganised sector where almost all the workers are 
informal, but also in the organised sector where the percentage of workers employed as informal workers has increased in recent years. A striking trend in recent decades has been the rise in informal workers in the organised sector. Compared to only 38 per cent of workers employed as informal workers in the organised sector in 1999-2000, there were 56 per cent of workers employed as informal workers in the organised sector by 2011-12. Further disaggregation in the public and private sector suggests that it is the private organised sector that employs a significant number of the informal workers, where the rate is almost two-thirds of all workers.

\section{Uneven distribution of the gains from growth}

Labour market outcomes are primarily a result of gains from growth being unevenly distributed. Some attribute this to the pattern of capital accumulation during the post-reform period, which has not generated the required structural changes in the economy. Chandrasekhar and Ghosh (2014) characterise the Indian system of capital accumulation as one of 'exclusion through incorporation', particularly in the neo-liberal period. The growth strategy has not included measures to enable mass consumption of goods. In the absence of sufficient measures, inequalities in the system have persisted and even intensified. Financial institutions, input and product markets and insufficient access to credit also intensify this problem. Social institutions and political forces allow discriminatory labour practices to continue, and legal and regulatory institutions enhance the bargaining power of capital. Governments have aided the existing capital accumulation process by allowing corporate tax exemptions, appropriation of land and natural resources and by lax implementation of regulations.

The Annual Survey of Industries (ASI) reveals the emoluments received by various categories of workers. Figure 8.10 presents the wages of production workers, supervisors and managerial staff in the organised manufacturing sector. While workers' wages and the emoluments of managerial staff moved in tandem until the 1980s, they have diverged since the early 1990s. By 2012, the last year for which data is available, managerial emoluments increased by more than 10 times, while worker's wages have increased by less than four. 


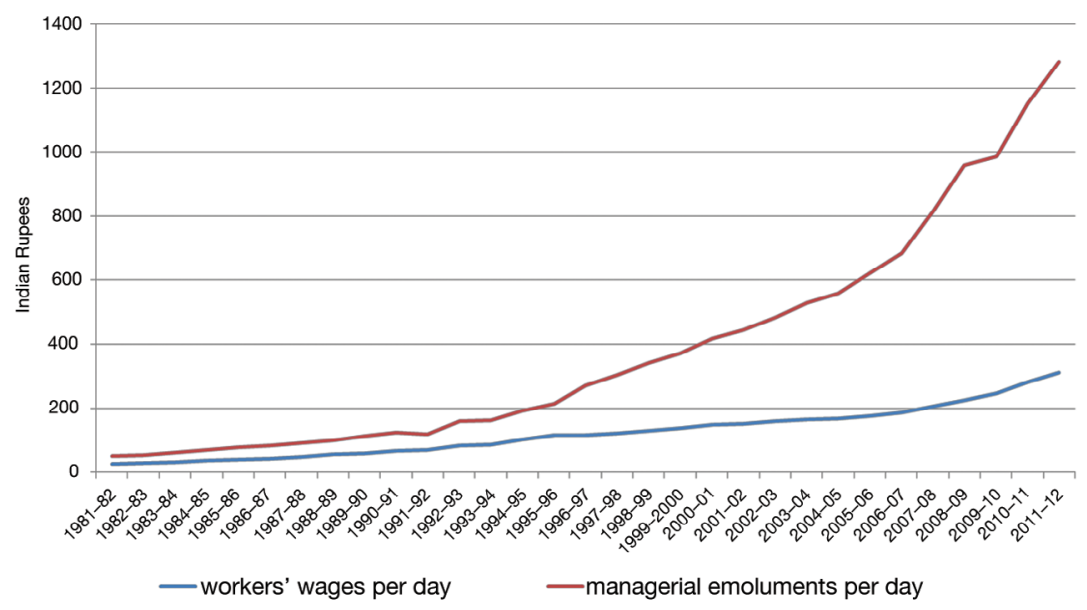

Figure 8.10. Workers' wages and managerial emoluments in organised manufacturing

Source. Author's computation from ASI data

The ASI data also sheds light on the fact that increased productivity has not improved the circumstances of workers. Workers' share in net value added has been suppressed at the cost of profits. Figure 8.11 illustrates the share of wages and profits out of net value added in organised manufacturing. While wage share was higher in the early 1980s, at around 30 per cent with profit share at only 20 per cent, the share changed after the 1990s. In recent years, the share of profits in net value added has increased to more than 50 per cent, reaching a peak of more than 60 per cent in 2007-08. While it declined after the financial crisis, it continues to be above 50 per cent of net value added in organised manufacturing. During the same period, the share of wages in value added declined to 10 per cent and has remained thereabout in recent years. The compression in wage share was accompanied by taking recourse to contractualisation and casualisation of the organised manufacturing workforce.

While increased inequality among workers in the organised sector is only a small component of overall inequality, it emphasises the changing nature of production in the organised sector. 


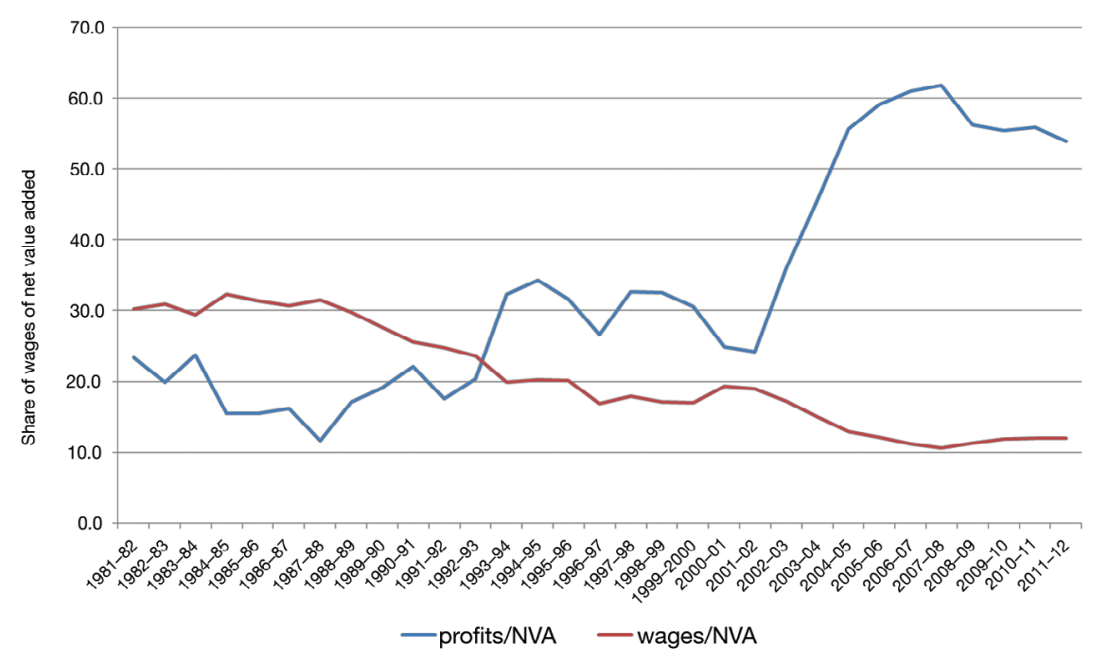

Figure 8.11. Share of profits and wages out of net value added (NVA) in organised manufacturing (ASI)

Source. Author's computation from ASI data

\section{Pro-poor policies}

While the post-1991 policies of structural adjustment and liberalisation of the economy undoubtedly saw the fastest rise in inequality, they also contributed to unprecedented distress in the rural economy. The ruling National Democratic Alliance (NDA) government, which sought votes in the name of 'India Shining', lost the election in 2004 because of unrest and distress in rural areas. ${ }^{13} \mathrm{~A}$ renewed focus on rural areas introduced by the new government of 2004-05 alleviated the unrest to an extent. While the overall direction of the economy did not change compared to the post-1991 period, inequality increased more slowly due to a shift towards pro-poor policies. A massive increase in spending on rural areas resulted in most rural poor benefiting from expansion of the Public Distribution System (PDS) and other food-related schemes (Himanshu \& Sen 2013). This was also the case with other measures such as the Mahatma Gandhi National Rural Employment Guarantee Scheme (MGNREGS), which contributed to increasing the demand for non-farm labour. Farmers, on the other hand, benefited from generous increases in minimum support

13 While it is simplistic to argue that the rise in inequality contributed to the downfall of the NDA government, the claims of 'India Shining' certainly did not find favour with the rural population, which saw the slogan as an affront to their misery. 
prices (MSP) and loan waivers that contributed to the raising of real incomes. The cumulative impact of the MGNREGS and MSP increase saw a significant increase in casual wage rates in rural areas, which later spilled over to urban areas. Figure 8.12 gives the real casual labour wages at 2011-12 prices. The period between 2008 and 2013 saw real wages increase at more than 6 per cent per annum, which was faster than the growth of average per capita incomes. While income concentration at the top continued to rise, and this period was also characterised by a rise in crony capitalism, the rise in inequality was moderated by the shift in policy that benefited the bottom half of the population.

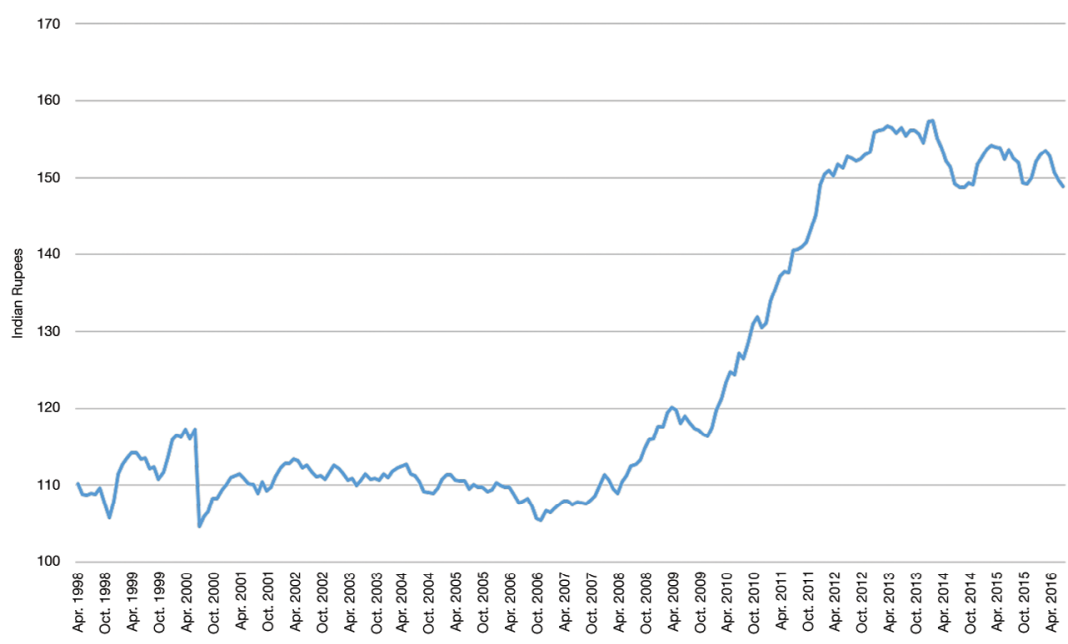

Figure 8.12. Real wages of unskilled labour, 2011-12 prices

Source. Labour Bureau

While government policies contributed to the rise in household incomes at the bottom end of the distribution, it did not result in a significant decline in inequality, unlike in the 1980s in rural areas. This is partly because the inequality that exists in the labour market has seen workers lose on account of a lack of jobs but also due to worsening employment quality. While the pro-poor orientation of the government contributed to moderating the rise in inequality, it was assisted in this by the speed of economic growth that, at 8.5 per cent per annum between 2004-05 and 2011-12, provided revenue for the government to undertake these fiscal measures. 


\section{Inequality and intergenerational mobility}

Three conclusions can be drawn from the preceding analysis, 1) India is among the countries with the highest level of inequality; 2) inequality in India has been rising over the last three decades, in contrast with most countries that have experienced a decline in inequality; and 3) two episodes of growth acceleration have produced different outcomes as far as inequality is concerned, with the economic acceleration in the 1980 s accompanied by declining or stagnant inequality but a sharp rise in inequality post-1991.

What does this mean for individual mobility? Outcomes are determined not only by the existing state of income distribution, but are more dependent on inequality of opportunity. Inequality of opportunity is not an outcome of access to employment and assets alone. Horizontal inequalities, based on where an individual is born and to which caste, community, religion, region and gender, also affect equal access to opportunities (Stewart 2002), due to prejudice, marginalisation and discrimination. Horizontal inequalities affect an individual's participation in the labour market in isolation but also in conjunction with other identities such as caste, which can determine occupational choices. While these barriers have weakened, evidence points to a perpetuation of certain caste groups being employed in certain occupations. Most workers performing menial and dirty jobs come from among the scheduled castes and there are few employed in higher education, the judiciary, media or professional occupations. This is similarly the case with segregation on the basis of religion and gender when inequality manifests itself in access to employment opportunities and in wage gaps across caste or gender.

\section{Intergenerational mobility in India}

There is limited information available on intergenerational mobility in India. This is partly because data that can track changes in the economic fortunes of households/individuals over generations is also limited. Some research, however, has utilised the repeated cross-sectional nature of consumption surveys to identify trends in intergenerational mobility, and panel data from IHDS has also been used to arrive at estimates of intergenerational mobility. 
Using IHDS (2004-05) data, Rama et al. (2015) report mobility of fathers and sons for a broad range of occupations including unskilled workers, farmers, skilled or semiskilled workers, and white-collar workers. ${ }^{14}$ They report substantial mobility in occupations across generations with over 40 per cent of the children of unskilled workers and 36 per cent of the sons of farmers engaged in occupations other than their fathers'. They also break down the fathers' age by 10-year cohorts and report increased mobility over generations. Their review of mobility by caste and religious groups finds no difference between mobility of Muslims and Hindus, but higher mobility among disadvantaged caste groups such as scheduled castes (SC) and scheduled tribes (ST) compared to forward castes.

These findings are confirmed by other studies. Using NSSO surveys, Hnatkovska et al. (2013) reported higher mobility among disadvantaged groups compared to general castes and found this to be true for occupational transition and educational attainment. Their finding is similar to work by Dang and Lanjouw (2015) who created a longitudinal panel to analyse change in poverty levels among households using NSSO consumption surveys. On the other hand, using the IHDS data, Motiram and Singh (2012) report considerable persistence of occupations across generations and low-paying jobs among the SC/ST groups.

Azam (2016), Mohammed (2017) and Chakraborty et al. (2016) use the panel data from NCAER surveys to examine intergenerational mobility. Azam finds considerable difference between mobility of forward (higher) castes versus lower castes (SC/ST) and, using data from 199394, 2004-05 and 2011-12, he reports the highest upward and lowest downward mobility among the forward castes and the reverse for the ST. He also reports the lowest mobility among Muslims in the 2004-11 period. On the other hand, using the same data set, Mohammed reports estimates of intergenerational elasticities that lie between 0.28 and 0.37 , which is lower than estimates from other countries. While within-group mobility among SC/ST households is found to be high, Mohammed reports low between-group convergences. Chakraborty et al. (2016) use the Rural Economic and Demographic Survey (REDS) data to analyse the role of formal networks in intergenerational mobility. They report an 11.5 per cent increase in mobility among sons compared to fathers due to the presence of formal networks. Similarly, mobility away from traditional

14 The occupation of fathers is reported by sons and is subject to biases and recall errors. 
occupations is 31.1 per cent in the presence of formal networks. Thorat et al. (2017) use IHDS data to analyse the relative probabilities of falling and escaping poverty. They report that all groups have done well in terms of escaping poverty between 2004 and 2011, but SC and ST groups have less chance of escaping poverty compared to forward castes. Ranganathan et al. (2016) also use IHDS data to conclude persistence in lower quintiles among backward castes and higher quintiles among forward castes. They also report higher intertemporal mobility among SC and backward castes.

The broad conclusion of these studies points towards a rise in intergenerational mobility although SC/ST groups continue to face disadvantage. While most of these studies have used occupation as the proxy for mobility, it is difficult to obtain information on earnings from different occupations for different generations.

\section{Intergenerational mobility from Palanpur surveys}

While the evidence on intergenerational inequality from large surveys is mixed, there is no study that has attempted an analysis of inequality and intergenerational mobility. This is understandable given the lack of long-time series data, including availability of income distribution across generations. Krueger (2012) and Corak (2013) point out that countries with high inequality are associated with relatively low intergenerational income mobility. Using the elasticity of a son's lifetime earnings with respect to his father's lifetime earnings, Corak (2013) introduces the idea of the 'Great Gatsby curve' to plot the relationship between intergenerational elasticity of income and a cross-sectional measure of income inequality, the Gini coefficient. ${ }^{15}$

The mobility of individuals and households is not just dependent on individual effort, talent and assets but also depends on social identity, horizontal inequalities, public policy and the social and political environment. A consequence of high inequality is its impact on public services. In societies where inequality is high, the wealthy can often buy

15 The Great Gatsby curve shows a positive relationship across countries, where higher inequality in a given country at a given point in time is associated with lower intergenerational mobility (a higher intergenerational elasticity of earnings). 
basic services and leave the public services for the poor ${ }^{16}$. But even in a case of individual effort, talent and assets, the acquisition of these depend on the relative position of the father.

While cross-country studies confirm such a relationship, its mechanism is more likely to operate at the micro level. The effect of inequality at village or town level is likely to be more pronounced since what matters for individuals is their close surroundings and the availability of public services and employment opportunities.

An examination of the relationship between income inequality and intergenerational mobility can be usefully undertaken in the case of rural India, specifically through the surveys of Palanpur, a small village in western Uttar Pradesh. It is not representative of India's half a million or so villages in its social and economic structure, but it is uniquely endowed with data suited to the study of intergenerational mobility over a long period of time. There have been seven rounds of Palanpur surveys, once in each decade starting from 1957-58, with the last being 2015. It has been surveyed in 1963, 1974, 1983, 1993, 2008-10 and 2015. The uniqueness arises also from the close attention to data quality paid by successive researchers who undertook a complete census of the village in each survey round. Some of these survey rounds have involved long stays in the village, with the 2008-10 survey lasting a full two years.

For all the survey rounds except 1993 and 2015, meticulously collected income estimates for all the resident households of the village are available. ${ }^{17}$ These have now been made comparable and consistent with a common definition. The longitudinal nature of the data collection allows one to compare the income, occupation and other characteristics of children with fathers for two generations. ${ }^{18}$

Between 1957-58 and 1963, there was a marginal increase in inequality in the village, with the Gini coefficient rising from 0.336 to 0.353 . But it declined to 0.272 in the next round of 1974 , the lowest inequality ever in

16 See Sinha (2016) and Sinha et al. (2016) for inequality and collective action for public services. 17 Unlike most empirical analyses of distributional change at the village level, the Palanpur study has taken as its reference domain not just a sample of households in a particular village or locality, but the entire population of the village. All households in the village were surveyed and interviewed, and income data were collected for the entire population for five out of the seven survey years.

18 See Himanshu et al. (2013) for details on inequality trends and decompositions. 
the village. ${ }^{19}$ Between 1975 and 1983 inequality increased, but remained lower than its 1957-58 and 1963 levels. ${ }^{20}$ The survey conducted in 2008-10, the Gini index, at 0.379, is at its highest level compared to all other survey years. The rise in inequality since the late 1970s mirrors the rise in inequality reported earlier for all India. The increase in inequality after 1983 is largely driven by the non-farm sector but inequality has also risen within caste groups. While within-group differences are large and have increased over time in Palanpur, there has been a decline in income differences between caste groups. This observation applies even when the population is divided into two groups, Jatabs - historically the most socially and economically disadvantaged group in the village - and the rest of the village. Using classical inequality decomposition as well as the Elbers, Lanjouw, Mistiaen, Özler (ELMO) decomposition, ${ }^{21}$ there is strong evidence of an improvement in the condition of Jatabs as a group, relative to the rest of the village population. The improvement in the condition of Jatabs is a result of improved incomes in agriculture, which has allowed some of them to lease land, and the availability of non-farm jobs. Expansion of non-farm job opportunity has allowed individuals belonging to various groups to look beyond their historical agricultural occupations and to explore new ventures.

The unique Palanpur data, with income data available for more than two generations, permits examination of intergenerational mobility across generations in the village. The long period of surveys allows tracking and

19 The remarkable decline between 1963 and 1974 was the consequence of three principal factors. First, with the investment in irrigation in the 1960s and the advent of green revolution methods in the late 1960s and 1970s there was a significant expansion in the use and application of modern agricultural technologies, introduction of newer farming practices and better irrigation devices. The distributional 'incidence' of the expansion of irrigation was particularly progressive in that, whereas previously only a few, better-off, farmers were in a position to irrigate their land (using 'Persian wheel' lifting technologies that required the digging and maintenance of a large well and complementary draught animal power), this period saw the expansion of irrigation to all farmers. By 1974-75, all village land was irrigated. Second, that year was also a particularly good agricultural year in terms of harvest quality in Palanpur. As a result, those who had spent less on inputs were less at risk from lower or negative incomes in the face of a bad harvest. And 'errant' farming practices (e.g. late sowing, poor weeding) tended to be less severely penalised. The third factor to contribute towards an equalisation of income in 1974-75 was that the distribution of land cultivated in Palanpur was more equal in 1974-75 than in other years.

20 The increase in inequality in 1983-84 can be attributed to the emergence of new, non-farm employment opportunities that were taken up mostly by villagers from economically better-off backgrounds. Also, 1983-84 was a bad agricultural year that led to further widening of the income gaps between those who derived some earnings from outside and those who were entirely dependent on agriculture.

21 The ELMO method offers a reinterpretation of sub-group inequality following the method suggested in their paper. For details see, Elbers, Lanjouw, Mistiaen and Özler (2008). 
assessing of changes in intergenerational elasticity over two generations. Intergenerational elasticity in income can be calculated for two periods, $1957-58$ to $1983-84$ and $1983-84$ to $2008-10$, each with a gap of 25 years. Father-son pairs can be identified for each period, with sons in the latter period being 25-35 years of age. The per capita income of the household in the initial period is assumed to be the father's income. ${ }^{22}$ The following model is estimated:

$$
\log \left(\text { income }_{\text {son }}\right)=\alpha+\beta \log \left(\text { income }_{\text {father }}\right)+\varepsilon
$$

Where income ${ }_{\text {son }}$ is the per capita household income in the latter period and income $e_{\text {father }}$ is the per capita household in the former period. Table 8.4 reports the estimated elasticities.

Table 8.4. Intergenerational elasticity in earnings and inequality (1958-2009)

\begin{tabular}{|l|r|r|r|r|}
\hline & \multicolumn{1}{|c|}{$\begin{array}{c}\text { 1958-84 } \\
\text { (1) }\end{array}$} & \multicolumn{1}{|c|}{$\begin{array}{c}\text { 1984-2009 } \\
\text { (2) }\end{array}$} & \multicolumn{1}{|c|}{$\begin{array}{c}\text { 1958-74 } \\
\text { (1984) } \\
\text { (3) }\end{array}$} & $\begin{array}{c}\text { 1974 } \\
\text { (1983)-2009 } \\
\text { (4) }\end{array}$ \\
\hline $\begin{array}{l}\text { Number of observations (in the age } \\
\text { group 25-35 years) }\end{array}$ & 58 & 100 & 58 & 100 \\
\hline Gini coefficient in terminal year & 0.336 & 0.379 & 0.235 & 0.379 \\
\hline Intergenerational elasticity & 0.328 & 0.396 & 0.294 & 0.441 \\
\hline
\end{tabular}

Note. Columns 3 and 4 represent the elasticity replacing the income for 1983-84 by an average of 1974-75 and 1983-84 because 1974-75 was a good agricultural year and 1983-84 was a bad year.

Source. Author's computation from Palanpur survey data

Higher income inequality is observable as being associated with higher intergenerational income elasticity (and thus lower mobility), which is consistent with Corak (2006). An increase in intergenerational elasticity over time is also observable, as is a rise in overall inequality as measured by the Gini coefficient. Alternative estimates confirm the robustness of the result by taking the average of incomes of 1974-75 and 1983-84, since 1983-84 was a bad year in terms of agricultural production. The increase in intergenerational elasticity is even more pronounced in this case. Interestingly, the estimates of intergenerational elasticity are not very different from 0.396 and are 0.441 for the $1983 / 84-2008 / 09$ period are broadly in line with the findings from Mohammed (2016) using IHDS

22 In other words, if the son lies in the working age group of 25-35 years and is part of the household in 2008-09, then the per capita income of the household in 1983-84 is considered as his father's income. 
data for the later period. Even earnings elasticity reported by Atkinson et al. (1983) between sons and fathers of 0.436 in the town of York over the period 1950 to $1975-78$ is similar.

One of the possible routes through which intergenerational elasticity is presumably influenced is inheritance passed on to successive generations, and more so in an agrarian economy like Palanpur. The emergence of nonfarm labour as an alternative source of income should, however, break the rigidities in income and wealth transmission. While this is the case in Palanpur, the nature of non-farm diversification has been such that access to these jobs has varied across caste and income strata for different nonfarm jobs. Jatabs and households at the lower end of the income strata have mostly been restricted to manual casual labour when accessing nonfarm jobs. On the other hand, the expansion of non-farm opportunities has not led to a weakening of the role of education and networks, which played a role in non-farm diversification during earlier surveys. These were more important for accessing regular, well-paying, non-farm jobs, which remain concentrated amongst Thakur and other advantaged households that have better access to networks and can finance 'entrance fees' or bribes. Networks are important in the case of casual jobs and there is evidence of them playing an important role for Jatabs in accessing non-farm jobs. The new non-farm opportunities create possibilities for upward mobility and, within any group, some move to take these opportunities more quickly than others. Nevertheless, income and social status increase the likelihood of obtaining these non-farm jobs, and this effect becomes more important in overall structures as the number of non-farm opportunities rise.

\section{Intergenerational mobility in Asia}

Although important, studies on intergenerational mobility are rare. Part of the problem is the availability of data that allows tracking of individual/ households over a period of time. This is particularly so for developing countries but, even for developed countries, few studies are available. ${ }^{23}$ How does India and Palanpur compare to other countries in Asia? Most Asian countries, except Japan, have moved from developing into the category of developed countries. Each has followed its own path of national transformation and is beset with social and political issues that define the nature of intergenerational mobility.

23 See Atkinson (1981); Aaronson and Mazumder (2008); Björklund and Jäntti (1997); Corak (2011); Lefranc and Trannoy (2005); Leigh (2007); and Solon (2002). 
Among the Asian countries, India and China are often compared for the size of their populations, but also because of the complexity of their social structures. The recent rise of China has attracted attention to the issue of inequality and intergenerational mobility. Similar to India, China also experienced rising inequality during the period of growth acceleration after the 1980s. Fan et al. (2015) examine the issue of intergenerational mobility in China using data from the Chinese Household Income Project (CHIP). They conclude that the rise in Gini coefficient of income from 0.26 in 1980 to 0.43 in 2010 has been accompanied by a decline in intergenerational mobility in income and education. The intergenerational income elasticity increases from 0.315 to 0.442 between cohorts born before and after 1970. They also report a significant decline in elasticity in the case of females and residents in economically disadvantaged regions within China. The cross-sectional analysis of intergenerational mobility and income inequality confirms the presence of a Great Gatsby curve. Deng et al. (2013) also confirm the lack of intergenerational mobility in the case of China.

On the other hand, Lam and Cuong (2017) show high mobility across income quintiles in the case of Vietnam. Using data from the Vietnam Household Living Standard Surveys (VHLSS), they also find the degree of mobility declining over time but still at a high level. The intergenerational elasticity of earnings for parents and children at around 0.36 is, however, stable over 2004 and 2014. Kim (2015) reports a high degree of mobility in South Korea and, in Asia, South Korea and Japan are seen as examples of countries with high income and occupational mobility along with low inequality. In fact, in both these countries the level of inequality is similar to the Nordic countries of Denmark, Finland, Norway and Sweden. South Korea and Japan are also examples of countries that have seen rapid growth in per capita income without a rise in income inequality. Using the Japan Household Panel Survey (JHPS), Ueda (2015) estimates intergenerational income elasticity among fathers and sons to be in the range of $0.32-0.34$. Another country that shows stable intergenerational mobility is Taiwan. Despite high economic growth, Chu and Lin (2016) report stable intergenerational income elasticity in Taiwan between 1990-94 and 2005-10. 
In most cases, the estimates of intergenerational elasticity in Asian countries are broadly in the range for India that is reported using the national surveys and Palanpur surveys. This is so except in the case of China, which shows a decline in intergenerational mobility, whereas most others show stable elasticities and high intergenerational mobility.

\section{Conclusion}

The debate on the performance of the Indian economy in recent decades has moved away from the concerns of an economy trapped in low-growth equilibrium to one among the fastest growing economies. Although growth has slowed in recent years, India continues to be among the countries with a reasonably high rate of growth. The issue that needs to be debated, however, is whether the growth is sustainable or not.

These concerns are not just academic but are being debated politically as well. The growth of the economy in the last three decades has coincided with a period of jobless growth and acute farm crisis, which continues to remain an economic and political challenge. The pattern of growth has increased incomes and reduced poverty but also led to an increasing gap between a majority of labourers stuck in farming and the informal sector with poor working conditions. The livelihood and wellbeing of these individuals are also affected by the persistence of inequalities of caste, religion, region and gender, all of which contribute to exclude and marginalise a large segment of the population. These issues are appearing as political fissure points, with anger among the Dalits (SC) leading to demands for community-based reservation.

Inequality has largely been driven by changes in the labour market, with an increasing share of capital reserved for the cost of labour. The rise in profit rate has accompanied the decline in wage share. But it has also been accompanied by rising inequality in access to public services such as health and education. This has also led to concerns of crony capitalism. But whether the process of growth is sustainable depends not just on economic policies but also policies on human development and inclusion. The evidence from intergenerational mobility provides a mixed picture, with the poor and the disadvantaged experiencing an overall increase in access to non-farm jobs but it also shows persistence of caste-based rigidities. In the long run, inequality is not just a matter of moral and 
philosophical concern but is also instrumental in sustaining the growth of the economy through allowing the disadvantaged to participate in and benefit from the growth process.

\section{References}

Aaronson, D \& Mazumder, B (2008). 'Intergenerational economic mobility in the United States: 1940-2000', Journal of Human Resources, 43(1), 139-72. doi.org/10.3368/jhr.43.1.139.

Abraham, V (2017). 'Stagnant employment growth: Last three years may have been the worst', Economic and Political Weekly, 52(38), 13-17.

Anand, I \& Thampi, A (2016). 'Recent trends in wealth inequality in India', Economic \& Political Weekly, 51(50), 59-67.

Atkinson, A (1981). 'On intergenerational income mobility in Britain', Journal of Post-Keynesian Economics, 3, 194-218. doi.org/10.1080/01603477.1980. 11489214.

Atkinson, AB, Maynard, AK \& Trinder, CG (1983). Parents and children: Incomes in two generations. London: Heinemann.

Azam, M (2016). Household income mobility in India: 1993-2011, IZA Discussion Papers, 10308. Institute for the Study of Labor (IZA).

Banerjee, A \& Piketty, T (2005). 'Top Indian incomes, 1922-2000', The World Bank Economic Review, 19(1), 1-20. doi.org/10.1093/wber/lhi001.

Björklund, A \& Jäntti, M (1997). 'Intergenerational income mobility in Sweden compared to the United States', American Economic Review, 87(5), 1009-18.

Chakraborty, T, Mukherjee, A, Sahaz, S \& Shekhawat, AS (2016). 'Formal institutions, caste network and occupational mobility', conference paper, 12th Annual Conference on Economic Growth and Development, ISI Delhi.

Chakravorty, S, Chandrasekhar, S \& Naraparaju, K (2016). Income generation and inequality in India's agricultural sector: The consequences of land fragmentation, No. 2016-028. Mumbai: Indira Gandhi Institute of Development Research.

Chancel, L \& Piketty, T (2017). Indian income inequality, 1922-2014: From British Raj to Billionaire Raj?, No. 12409, CEPR Discussion Papers.

Chandrasekhar, CP \& Ghosh, J (2014). Growth, employment patterns and inequality in Asia: A case study of India, ILO Asia-Pacific Working Paper Series. 
Chu, Y-WL \& Lin, M-J (2016). Economic development and intergenerational earnings mobility: Evidence from Taiwan, working paper, Department of Economics, National Taiwan University, www.econ.ntu.edu.tw/uploads/asset/ data/58325b6248b8a17a8b03f89f/hist_1051208.pdf.

Corak, M (2006). 'Do poor children become poor adults? Lessons from a crosscountry comparison of generational earnings mobility', Research on Economic Inequality, 13, 143-88. doi.org/10.1016/S1049-2585(06)13006-9.

(2011). Generational income mobility in North America and Europe. Cambridge University Press.

(2013). 'Income inequality, equality of opportunity, and intergenerational mobility', Journal of Economic Perspectives, 27(3), 79-102. doi.org/10.1257/ jep.27.3.79.

Credit Suisse (2017). 'Global Wealth Report', November 2017. www.credit-suisse. com/articles/news-and-expertise/2017/11/en/global-wealth-report-2017.html.

Dang, H-A \& Lanjouw, PF (2015). Poverty dynamics in India between 2004 and 2012: Insights from longitudinal analysis using synthetic panel data, World Bank Policy Research Paper, 7270. doi.org/10.1596/1813-9450-7270.

Deng, Q, Gustafsson, B \& Li, S (2013). 'Intergenerational income persistence in urban China', Review of Income and Wealth, 59(3), 416-36. doi.org/10.1111/ roiw. 12034 .

Dev, MS (2017). 'Inequality, employment and public policy', Presidential address, Indian Society of Labour Economics, 2017.

Elbers, C, Lanjouw, P, Mistiaen J \& Özler, B (2008). 'Reinterpreting betweengroup inequality', The Journal of Economic Inequality, 6(3), 231-45. doi.org/ 10.1007/s10888-007-9064-x.

Fan, Y, Junjian Y \& Zhang, J (2015). 'The Great Gatsby curve in China: Crosssectional inequality and intergenerational mobility', conference paper, Asian Bureau of Finance and Economic Research, Singapore.

Himanshu (2007). 'Recent trends in poverty and inequality: Some preliminary results', Economic \& Political Weekly, 42(6), 497-508.

- (2015). 'Inequality in India', SEMINAR, August, www.india-seminar. com/2015/672/672_himanshu.htm.

Himanshu \& Sen, A (2013). 'In-kind food transfers - I: Impact on poverty', Economic and Political Weekly, 48(45/46), 46-54. 
Himanshu, Jha, P \& Rodgers, G (eds) (2016). The changing village in India: Insights from longitudinal research. Oxford University Press. www.oxfordscholarship. com/view/10.1093/acprof:oso/9780199461868.001.0001/acprof-9780199 461868 .

Himanshu, Joshi, B \& Lanjouw, P (2016). 'Non-farm diversification, inequality and mobility in Palanpur', Economic and Political Weekly, 51 (26 \& 27), 43-51. doi.org/10.1093/acprof:oso/9780199461868.003.0011.

Himanshu, Lanjouw, P, Murgai, R \& Stern, N (2013). Non-farm diversification, poverty, economic mobility and income inequality: A case study in village India, Policy Research Working Paper Series, 6451. The World Bank.

Hnatkovska, V, Lahiri, A \& Paul, SB (2013). 'Breaking the caste barrier: Intergenerational mobility in India', Journal of Human Resources, 48(2), 435-73. jhr.uwpress.org/content/48/2/435.short.

Jayadev, A, Motiram, S \& Vakulabharanam, V (2007). 'Patterns of wealth disparities in India during the liberalisation era', Economic and Political Weekly, 42(38), 3853-63.

Kim, T (2015). 'Intergenerational economic mobility in Korea: Assessment, drivers, and lessons'. In T Kim \& A Mulakala (eds), Social mobility: Experiences and lessons from Asia (pp 7-21). Korea Development Institute and The Asia Foundation, South Korea.

Krueger, A (2012). 'The rise and consequences of inequality in the United States', 12 January, speech, Center for American Progress, Washington D.C.

Lam, NT \& Cuong, NV (2017). Intragenerational and intergenerational mobility in Viet Nam, ADBI Working Paper, 722. Tokyo: Asian Development Bank Institute.

Lefranc, A \& Trannoy, A (2005). 'Intergenerational earnings mobility in France: Is France more mobile than the US?', Annales d'Economie et de Statistique, 78, 57-77. doi.org/10.2307/20079128.

Leigh, A (2007). 'Intergenerational mobility in Australia', The B.E. Journal of Economic Analysis and Policy, 7(2), Article 6. doi.org/10.2202/1935-1682.1781.

Li, H, Squire L \& Zhou, H-F (1998). 'Explaining international and intertemporal variation in income inequality', The Economic Journal, 108(446), 26-43. doi.org/10.1111/1468-0297.00271.

Mazumdar, D, Sarkar, S \& Mehta, BS (2017). 'Inequality in India - I', Economic and Political Weekly, 52(30), 47-56 and 'Inequality in India - II: The wage sector', Economic and Political Weekly, 52(32), 58-66. 
Mohammed, ARS (2017). 'Does a good father now have to be rich? Intergenerational income mobility in rural India', SSRN, www.isid.ac.in/ - epu/acegd2016/papers/ShariqMohammed.pdf.

Motiram, S \& Singh, A (2012). 'How close does the apple fall from the tree? Some evidence from India on intergenerational occupational mobility', Economic and Political Weekly, 47(40), 56-65.

Piketty, T (2014). Capital in the twenty-first century. Harvard University Press.

Rama, M, Béteille, T, Li, Y, Mitra, PK \& Newman, JL (2015). Addressing inequality in South Asia, South Asia Development Matters. Washington, DC: World Bank.

Ranganathan, T, Tripathi, A \& Pandey, G (2016). Income mobility among social groups in Indian rural households: Findings from the Indian Human Development Survey, IEG Working Paper, No. 368.

Rawal, V (2008). 'Ownership holdings of land in rural India: Putting the record straight', Economic and Political Weekly, 43-47.

Rawal, V \& Swaminathan, M (2011). 'Income inequality and caste in village India', Review of Agrarian Studies, 1(2), ras.org.in/income_inequality_and_ caste_in_village_india.

Rodgers, G \& Soundarajan, V (2015). Patterns of inequality in India, 19832011/12: project paper D (India). Institute of Human Development.

Sarkar, S \& Mehta, BS (2010). 'Income inequality in India: Pre- and post-reform periods', Economic and Political Weekly, 45(37), 45-55.

Sarma, M, Saha, P \& Jayakumar, N (2017). Asset inequality in India: Going from bad to worse, SSER Working Paper, 17/1.

Sen, A \& Himanshu (2004). 'Poverty and inequality in India - II: Widening disparities during the 1990s', Economic and Political Weekly, 39(39), 4361-75. www.epw.in/journal/2004/39/special-articles/poverty-and-inequality-indiaii.html.

Sinha, D (2016). Women, health and public services in India: Why are states different? Routledge. doi.org/10.4324/9781315626512.

Sinha, D, Tiwari, DK, Bhattacharya, R \& Kattumuri, R (2016). 'Public services, social relations, politics, and gender: tales from a north Indian village'. In Himanshu, P Jha \& G Rodgers (eds), The changing village in India: Insights from longitudinal research. Oxford University Press. doi.org/10.1093/acprof: oso/9780199461868.001.0001. 
Solon, G (2002). 'Cross-country differences in intergenerational earnings mobility', Journal of Economic Perspectives, 16, 59-66.

Stewart, F (2002). Horizontal inequalities: A neglected dimension of development, QEH Working Paper Series, No. 81.

Subramanian, S \& Jayaraj, D (2006). The distribution of household wealth in India, research paper, No. 2006/116. UNU-WIDER, United Nations University (UNU).

Swaminathan, M (1988). 'Growth and polarisation: Changes in wealth inequality in a Tamilnadu village'. Economic and Political Weekly.

Swaminathan, M \& Rawal, V (2011). 'Is India really a country of low income inequality? Observations from eight villages', Review of Agrarian Studies, 1(1), ras.org.in/is_india_really_a_country_of_low_income_inequality_ observations_from_eight_villages.

Thorat, A, Vanneman, R, Desai, S \& Dubey, A (2017). 'Escaping and falling into poverty in India today', World Development, 93, 413-26. doi.org/10.1016/ j.worlddev.2017.01.004.

Ueda, A (2015). An empirical analysis on intergenerational persistence of income in Japan, WINPEC Working Paper Series, No. E1511. Waseda Institute of Political Economy, Waseda University, Tokyo, Japan.

Vaidyanathan, A (1993). 'Asset holdings and consumption of rural households in India: A study of spatial and temporal variations'. In Indian Society of Agricultural Economics, Agricultural development policy: Adjustments and reorientation. New Delhi \& Oxford: Indian Society of Agricultural Economics. 
This text is taken from Achieving Inclusive Growth in the Asia Pacific, edited by Adam Triggs and Shujiro Urata, published 2020 by ANU Press, The Australian National University, Canberra, Australia.

doi.org/10.22459/AIGAP.2020.08 